Research Paper

\title{
Pseudolaric Acid B Induced Cell Cycle Arrest, Au- tophagy and Senescence in Murine Fibrosarcoma L929 Cell
}

Jing hua Yu1, Chun yu Liu², Gui bin Zheng33, Li Ying Zhang4, Ming hui Yan¹, Wen yan Zhang1, Xian ying Meng $^{3, \bowtie}$, Xiao fang $\mathrm{Yu}^{1, \bowtie}$

1. Institute of virology and AIDS research, The first hospital of Jilin University, 519 Dongminzhu Street, Changchun 130021, P. R. China;

2. Acupuncture department, The affiliated hospital to Changchun University of Chinese Medicine, 1478 Gongnong Road, Changchun 130021 , P. R. China;

3. Department of Thyroid Surgery, The First Hospital of Jilin University, 71 Qianjin Street, Changchun 130021, P. R. China;

4. Department of Biotechnology, College of Animal Science and Veterinary Medicine, Jilin University, Changchun 130062, P. R. China.

$\square$ Corresponding author: Department of Thyroid Surgery, The First Hospital of Jilin University, 71 Qianjin Street, Changchun 130021, P. R. China; Tel: (86) 431-88782144, Fax: (86) 431-88782144. Email: 497573398@qq.com; Institute of virology and AIDS research, The first hospital of Jilin University, 519 Dongminzhu Street, Changchun 130021, P. R. China. Tel: (86) 431-88782147, Fax: (86) 431-88782147. Email: xfyu@jhsph.edu.

(C) Ivyspring International Publisher. This is an open-access article distributed under the terms of the Creative Commons License (http://creativecommons.org/ licenses/by-nc-nd/3.0/). Reproduction is permitted for personal, noncommercial use, provided that the article is in whole, unmodified, and properly cited.

Received: 2012.12.17; Accepted: 2013.03.28; Published: 2013.04.09

\begin{abstract}
Objective: $\mathrm{PAB}$ induced various cancer cell apoptosis, cell cycle arrest and senescence. But in cell line murine fibrosarcoma L929, PAB did not induce apoptosis, but autophagy, therefore it was thought by us as a good model to research the relationship of cell cycle arrest, autophagy and senescence bypass apoptosis.

Methods: Inhibitory ratio was assessed by 3-(4,5-Dimethylthiazol-2-yl)-2,5-diphenyltetrazolium bromide (MTT) analysis. Phase contrast microscopy visualized cell morphology. Hoechst 33258 staining for nuclear change, propidium iodode (PI) staining for cell cycle, monodansylcadaverine (MDC) staining for autophagy, and rodanmine 123 staining for mitochondrial membrane potential (MMP) were measured by fluorescence microscopy or flowcytometry. Apoptosis was determined by DNA ladder test. Protein kinase C (PKC) activity was detected by PKC assay kit. SA- $\beta$-galactosidase assay was used to detect senescence. Protein expression was examined by western blot.

Results: PAB inhibited L929 cell growth in time-and dose-dependent manner. At $12 \mathrm{~h}, 80 \mu \mathrm{mol} / \mathrm{L}$ $P A B$ induced obvious mitotic arrest; at $24 \mathrm{~h}, \mathrm{PAB}$ began to induce autophagy; at $36 \mathrm{~h}$, cell-treated with $P A B$ slip into $G I$ cell cycle; and 3 d PAB induced senescence. In time sequence PAB induced firstly cell cycle arrest, then autophagy, then slippage into GI phase, lastly senescence. Senescent cells had high level of autophagy, inhibiting autophagy led to apoptosis, and no senescence. PAB activated PKC activity to induce cell cycle arrest, autophagy and senescence, inhibiting PKC activity suppressed cell cycle arrest, autophagy and senescence.
\end{abstract}

Conclusion: PAB induced cell cycle arrest, autophagy and senescence in murine fibrosarcoma L929 cell through PKC.

Key words: murine fibrosarcoma L929 cells; pseudolaric acid B (PAB); PKC; autophagy; cell cycle arrest; senescence.

\section{Introduction}

Pseudolaric acid B (PAB) was a diterpene acid isolated from the root and trunk bark of Pseudolarix kaempferi Gordon (Pinaceae), known as "Tu-Jin-Pi" which had been used to treat dermatological fungi 
infections by Chinese. PAB exerted potent cell growth inhibiory activity in vitro in various tumor lines through apoptosis [1-4], such as in human breast cancer MCF-7 cells, it was found that PAB induced cell apoptosis, cell cycle arrest and senescence [5, 6]. But in murine fibrosarcoma L929, PAB did not induce apoptosis, but autophagy [7], therefore it was concluded that so far PAB induced all the cell apoptosis except of L929 cell, and it was thought as a good model to research the relationship of cell cycle arrest, autophagy and senescence bypass apoptosis. Fibrosarcoma was a malignant mesenchymal tumour derived from fibrous connective tissue and characterized by the presence of immature proliferating fibroblasts or undifferentiated anaplastic spindle cells in a storiform pattern, there was no better method to treat it than surgery. The mechanism of anti-fibrosarcoma was clarified to be useful of fibrosarcoma treatment.

PAB was an anti-tubulin drug [8], same to other tubulin-related reagents taxanes (paclitaxel, docetaxel), the vinca alkaloids (vincristine and vinblastine), and nocodazole PAB suppressed microtubule dynamics, thus caused mitotic arrest [9-15]. Mitotic arrest had different results: (a) apoptosis during mitotic arrest and (b) mitotic slippage. Mitotic slippage also had different results, namely secondary apoptosis after mitotic slippage and G1 cell cycle arrest after mitotic slippage [16]. When mitotic slippage cells entered G1 phase of cell cycle, multinucleated cells were formed, and those multinucleated cells survived and became senescent [17]. Cellular senescence was referred to permanent arrest in the $G 1$ phase of the cell cycle [18]. Senescent cells had a flattened, enlarged morphology and exhibited specific molecular markers like senescence-associated- $\beta$-galactosidase, senescence-associated heterochromatin foci and the accumulation of lipofuscin granules [19, 20]. Autophagy was the process by which the cell's own components were delivered to lysosomes for bulk degradation. Autophagosomes had been shown to accumulate in senescent fibroblasts to facilitate the renewal of cytosolic compounds and organelles [21]. Recent studies had shown recombinant expression of autophagy genes (BNIP3, Cathepsin B or ATG16L1) in stromal fibroblasts was sufficient to induce the onset of constitutive autophagy as well as the development of senescence [22]. On the contrary, it was also found that autophagy impairment induced premature senescence in primary human fibroblasts [23]. Most researches focused on the relationship of between autophagy and senescence, or between cell cycle arrest and senescence. But less research was about triadic relationship of them in one experiment model. In this study we investigated the relationship of mitotic arrest, autophagy and senescence especially the sequence of events in one experiment model.

PKC enzymes were shown to play a role in G2/M transition. The suggested mechanism of PKC was suppression of cdc2 activity. But most of the published data strongly implicated PKC in lamin B phosphorylation and nuclear envelope disassembly $[24,25]$. In previous study Gong xianfeng found that PAB activated PKC to induce cell cycle arrest and apoptosis in HeLa cells, and PKC inhibitor staurosporine partly blocks this effect [4], therefore we investigated whether PKC was involved in autophagy and cell cycle arrest induced by PAB. Staurosporine, which was the inhibitor of conventional and novel PKC isoform, was a natural product originally isolated in 1977 from bacterium Streptomyces staurosporine [26], it was used comprehensively in experiment study as PKC inhibitor. In this study, to clarify the effect of PKC we used staurosporine and another PKC inhibitor Ro-31-8220 to find whether PAB exerted inhibitory role through $\mathrm{PKC}$, respectively.

\section{Materials}

PAB, which was purchased from the National Institute for the Control of Pharmaceutical and Biological Products (Beijing, China), was dissolved in dimethyl sulfoxide (DMSO) to make a stock solution. The senescence detection kit was purchased from Calbiochem (La Jolla, CA, USA). DMSO concentration was kept below $0.01 \%$ in all the cell cultures, and did not exert any detectable effect on cell growth or cell death. Propidium iodode (PI), monodansylcadaverine (MDC), rodamine 123, 3-Methyladenine (3-MA), staurosporine, Ro-31-8220, hoechst 33258, RNase A, 3-(4,5-dimethylthiazol-2-yl)-2,5-diphenyltetrazolium bromide (MTT) were purchased from Sigma Chemical (St. Louis, MO, USA). The senescence detection kit was purchased from Calbiochem (La Jolla, CA, USA). Rabbit polyclonal antibodies against LC3, cdc2, cyclinB1, $\quad \beta$-actin and horseradish peroxidase-conjugated secondary antibodies (goat-antirabbit or mouse) were obtained from Santa Cruz Biotechnology (Santa Cruz, CA, USA).

\section{Cell culture}

Murine fibrosarcoma L929, were obtained from American Type Culture Collection (ATCC, Manassas, VA, USA), and were cultured in DMEM medium (Hyclone, Logan, UT, USA) supplemented with 10\% heat inactivated $\left(56^{\circ} \mathrm{C}, 30 \mathrm{~min}\right)$ fetal calf serum (Beijing Yuanheng Shengma Research Institution of Biotechnology, Beijing), $2 \mathrm{mmol} / \mathrm{L}$ glutamine (Gibco, Grand Island, NY), penicillin $(100 \mathrm{U} / \mathrm{mL})$ and streptomycin $(100 \mu \mathrm{g} / \mathrm{mL})$, and maintained at $37^{\circ} \mathrm{C}$ with $5 \% \mathrm{CO} 2$ in a humidified atmosphere. 


\section{Cell growth inhibition test}

The inhibition of cell growth was determined by MTT test. L929 cells $\left(1.0 \times 10^{4}\right.$ cells/well $)$ were seeded into 96-well culture plates (Nunc, Roskilde, Denmark). After $24 \mathrm{~h}$ incubation, different concentration of PAB was added to the plates. Following incubation, cell growth was measured at different time points by addition of $20 \mu \mathrm{L}$ 3-(4,5-dimethylthiazol-2-yl)2,5-diphenyltetrazolium bromide (MTT, $5 \mathrm{mg} / \mathrm{mL}$ ) at $37^{\circ} \mathrm{C}$ for $3 \mathrm{~h}$, and DMSO $(150 \mu \mathrm{L})$ was added to dissolve the formazan crystals. Absorbance was measured at $492 \mathrm{~nm}$ with enzyme-linked immunosorbent assay plate reader (Bio-Rad, Hercules, CA, USA). The percentage of inhibition was calculated as follows:

Cell death $(\%)=\left[\mathrm{A}_{492}\right.$ (control) $-\mathrm{A}_{492}$ (sample) $] /\left[\mathrm{A}_{492}\right.$ (control) $-\mathrm{A}_{492}$ (blank) $] \times 100 \%$

\section{Observation of morphologic changes by light microscopy}

L929 cells $\left(5 \times 10^{5}\right.$ cells/well) were cultured in 6 wells plate for $24 \mathrm{~h}$. Then $80 \mu \mathrm{mol} / \mathrm{L} \mathrm{PAB}$, and/or 8 $\mathrm{nmol} / \mathrm{L}$ staurosporine, $8 \mathrm{\mu mol} / \mathrm{L}$ Ro-31-8220 were treated for $36 \mathrm{~h}$, morphologic changes were observed by phase contrast microscopy (Leica, Nusslich, Germany).

\section{Observation of nuclear morphologic changes}

L929 cells $\left(5 \times 10^{5}\right)$ were placed on the cover slips in a 6-well plate. After $24 \mathrm{~h}$ cell culture, they were treated with $80 \mu \mathrm{mol} / \mathrm{L} \mathrm{PAB}$ and/or $8 \mathrm{nmol} / \mathrm{L}$ staurosporine, $8 \mu \mathrm{mol} / \mathrm{L}$ Ro-31-8220 for $36 \mathrm{~h}$, or 80 $\mu \mathrm{mol} / \mathrm{L}$ PAB for $3 \mathrm{~d}$, then washed by PBS, fixed in $3.7 \%$ formaldehyde for $1 \mathrm{~h}$, then stained with $5 \mathrm{mg} / \mathrm{L}$ Hoechst 33258 for $30 \mathrm{~min}$. Nuclear changes were observed by fluorescence microscopy at excitation wave length $350 \mathrm{~nm}$ with emission filter $460 \mathrm{~nm}$ (Leica, Nusslich, Germany).

\section{Observation of mitochondrial membrane po- tential}

The rhodamine 123 staining intensity is intensified with the increased mitochondrial membrane potential. L929 cells were treated with $80 \mu \mathrm{mol} / \mathrm{L} \mathrm{PAB}$ for $3 \mathrm{~d}$, then were incubated with $5 \mu \mathrm{g} / \mathrm{ml}$ rhodamine 123 at $37^{\circ} \mathrm{C}$ for $30 \mathrm{~min}$. After incubation, the cells were washed once with PBS. The intensity of rhodamine 123 staining was measured by fluorescence microscopy at excitation wave length $505 \mathrm{~nm}$ with emission filter $534 \mathrm{~nm}$ (Leica, Nusslich, Germany).

\section{Observation of monodansylcadaverine (MDC) staining by fluorescence microscopy [27]}

A fluorescent compound, monodansylcadaverine (MDC) has been proposed as a tracer for autophagic vacuoles. L929 cells were treated with 80 $\mu \mathrm{mol} / \mathrm{L}$ PAB for 3 days, then were incubated with $0.05 \mathrm{mmol} / \mathrm{L} \mathrm{MDC}$ at $37{ }^{\circ} \mathrm{C}$ for $1 \mathrm{~h}$. After incubation, cells were washed once with PBS. Intracellular MDC was measured by fluorescence microscopy at excitation wave length $380 \mathrm{~nm}$ with emission filter $525 \mathrm{~nm}$ (Leica, Nusslich, Germany).

\section{Flowcytometric analysis of cell cycle}

L929 cells $\left(1.0 \times 10^{6}\right)$ were harvested and rinsed with PBS. The cell pellets were fixed in $70 \%$ ethanol at $4{ }^{\circ} \mathrm{C}$ overnight. After washing twice with PBS, the cells were stained with $1.0 \mathrm{~mL}$ of PI solution containing PI $50 \mathrm{mg} / \mathrm{L}$, RNase A $1 \mathrm{~g} / \mathrm{L}$, and $0.1 \%$ Triton X-100 in sodium citrate $3.8 \mathrm{mmol} / \mathrm{L}$, followed by incubation on ice in the dark condition for $30 \mathrm{~min}$. The samples were analyzed by a FACScan flowcytometer (Becton Dickinson, Franklin Lakes, NJ, USA).

\section{Flowcytometric analysis of the MDC staining}

L929 cells $\left(1 \times 10^{6}\right.$ cells/bottle) were cultured in 25 $\mathrm{mL}$ culture bottle overnight, then harvested with different dose PAB for indicated time, and rinsed with PBS. Then the cells were stained with $0.05 \mathrm{mmol} / \mathrm{L}$ $\mathrm{MDC}$ at $37^{\circ} \mathrm{C}$ for $1 \mathrm{~h}$. After incubation, the cells were washed once with PBS. The samples were analyzed by a FACScan flowcytometer (Becton Dickinson, Franklin Lakes, NJ, USA).

\section{Flowcytometric analysis by the rhodamine $\mathbf{I} 23$ staining}

L929 cells were harvested and rinsed with PBS. Then the cells were stained with $5 \mu \mathrm{g} / \mathrm{ml}$ rhodamine 123 at $37^{\circ} \mathrm{C}$ for $30 \mathrm{~min}$. After incubation, the cells were washed once with PBS. The samples were analyzed by flowcytometry.

\section{Determination of DNA fragmentation by agarose gel electrophoresis}

Both adherent and floating cells were collected by centrifugation at $1,000 \times g$ for $5 \mathrm{~min}$. The cell pellet was suspended in cell lysis buffer [Tris- $\mathrm{HCl} 10 \mathrm{mM}$ $\mathrm{pH}$ 7.4, edetic (EDTA) acid $10 \mathrm{mM}$ pH 8.0, Triton-100 $0.5 \%]$, and kept at $4{ }^{\circ} \mathrm{C}$ for $30 \mathrm{~min}$. The lysate was centrifuged at $25,000 \times g$ for $20 \mathrm{~min}$. The supernatant was incubated with $20 \mathrm{~g} \cdot \mathrm{L}^{-1}$ RNase A $(2 \mu \mathrm{L})$ at $37{ }^{\circ} \mathrm{C}$ for $1 \mathrm{~h}$, then incubated with $20 \mathrm{~g} \mathrm{~L}^{-1}$ proteinase $\mathrm{K}(2$ $\mu \mathrm{L})$ at $37^{\circ} \mathrm{C}$ for $1 \mathrm{~h}$. The supernatant was mixed with 5 $\mathrm{M} \mathrm{NaCl}(20 \mathrm{~L})$ and isopropanol $(120 \mu \mathrm{L})$ at $-20{ }^{\circ} \mathrm{C}$ overnight, and then centrifuged at 25,000 $\times g$ for 15 min. Following discarding the supernatant, the DNA sediment was dissolved in TE buffer (Tris- $\mathrm{HCl} 10 \mathrm{mM}$ $\mathrm{pH}$ 7.4, EDTA $1 \mathrm{mM} \mathrm{pH} 8.0$ ), and separated by $2 \%$ agarose gel electrophoresis at $100 \mathrm{~V}$ for $50 \mathrm{~min}$.

\section{PKC activity}

PKC activity assay was carried out according to 
the instructions of the PepTag ${ }^{\circledR}$ Non-Radioactive Protein Kinase C Assay Kit (Promega). Briefly, the cells were washed once with PBS and lysed in lysis buffer, including $20 \mathrm{mmol} / \mathrm{L}$ Tris- $\mathrm{HCl}, 0.5 \mathrm{mmol} / \mathrm{L}$ EGTA, $2 \mathrm{mmol} / \mathrm{L}$ EDTA, $2 \mathrm{mmol} / \mathrm{L}$ dithiothreitol, 1 mmol/L phenylmethanesulfonyl fluoride (PMSF), and $10 \mathrm{mg} / \mathrm{L}$ leupeptin $(\mathrm{pH}$ 7.5). Assays were then performed at $30^{\circ} \mathrm{C}$ in a total volume of $25 \mu \mathrm{L}$ containing $5 \mu \mathrm{L} 5 \times$ PKC reaction buffer, $5 \mu \mathrm{L}$ PLSRTLSVAAK peptide, $5 \mu \mathrm{L}$ PKC activator, $1 \mu \mathrm{L}$ peptide protection solution, and $9 \mu \mathrm{L}$ sample. Reactions were initiated by the addition of $9 \mu \mathrm{L}$ sample and terminated after 30 min by incubation of the reaction mixture at $95^{\circ} \mathrm{C}$ for $10 \mathrm{~min}$. After adding $1 \mu \mathrm{L}$ of $80 \%$ glycerol, each sample was separated by $0.8 \%$ agarose gel electrophoresis at $100 \mathrm{~V}$ for $15 \mathrm{~min}$, then using bandscan 5 software analyze the band density. We thought that band density of medium group was 1 , then observed ratio of other group to medium group.

\section{SA- $\beta$-galactosidase detection}

The L929 cells $\left(1.5 \times 10^{5}\right.$ cells/well $)$ were seeded into 24-well culture plates (Nunc, Denmark). After overnight incubation, $80 \mu \mathrm{mol} / \mathrm{L}$ PAB was added to the plates. After $3 \mathrm{~d}$ of incubation of PAB. Following the protocol of the senescence detection kit, the culture medium were removed and the cells were washed once with $1 \mathrm{~mL}$ phosphate-buffered saline (PBS), then the cells were fixed with $0.5 \mathrm{~mL}$ of fixative solution at room temperature for 10-15 min. The staining solution mix was prepared in a polypropylene plastic tube. For each well, $470 \mu \mathrm{L}$ staining solution, $5 \mu \mathrm{L}$ staining supplement, and $25 \mu \mathrm{L} 20 \mathrm{mg} / \mathrm{mL}$ $\mathrm{X}$-gal in DMF were added. The cells were rinsed twice with $1 \mathrm{~mL}$ PBS; $0.5 \mathrm{~mL}$ of the staining solution mix was added to each well and then incubated at $37^{\circ} \mathrm{C}$ without $\mathrm{CO}_{2}$ overnight. The cells were observed under a microscope for the development of a blue color.

\section{Western blot analysis of protein expression}

L929 cells $\left(1 \times 10^{6}\right)$ were cultured in $25 \mathrm{ml}$ culture bottle for $24 \mathrm{~h}$, then were treated with $80 \mu \mathrm{mol} / \mathrm{L}$ $\mathrm{PAB}$, and/or $8 \mathrm{nmol} / \mathrm{L}$ staurosporine for indicated time. Both adherent and floating cells were collected and frozen at $-80^{\circ} \mathrm{C}$. Western blot analysis was performed for total proteins as follows. Briefly, the cell pellets were resuspended in lysis buffer, including Hepes $50 \mathrm{mmol} / \mathrm{L} \mathrm{pH} \mathrm{7.4,1 \%} \mathrm{Triton-X} \mathrm{100,} \mathrm{sodium}$ orthovanadate $2 \mathrm{mmol} / \mathrm{L}$, sodium fluoride $(\mathrm{NaF}) 100$ $\mathrm{mmol} / \mathrm{L}$, edetic acid $1 \mathrm{mmol} / \mathrm{L}$, egtazic acid (EGTA) 1 $\mathrm{mmol} / \mathrm{L}$, phenylmethyl-sulfonylfluoride (PMSF) 1 $\mathrm{mmol} / \mathrm{L}$, aprotinin $0.1 \mathrm{~g} / \mathrm{L}$, leupeptin $0.01 \mathrm{~g} / \mathrm{L}$, then lysed in $4^{\circ} \mathrm{C}$ for $1 \mathrm{~h}$. After $13,000 \times$ g centrifugation for $10 \mathrm{~min}$, the protein content of the supernatant was determined using Bio-Rad protein assay reagent
(Bio-Rad, Hercules, CA, USA). Protein was loaded in onto nitrocellulose membrane. Protein expression was detected using primary polyclonal antibody (1:1000) and secondary polyclonal antibody (1:2000) conjugated with peroxidase.

\section{Statistical analysis}

All data represent at least three independent experiments, and are expressed as mean \pm S.D. Statistical comparisons were made using one-way ANOVA. ${ }^{* * *}$ P-values of less than 0.001 were considered to represent a statistically significant difference.

\section{Results}

\section{The inhibitory effect of PAB on L929 cells}

MTT analysis testified that inhibitory effect of PAB on L929 was in time and dose dependent manners. At $12 \mathrm{~h}$, IC50 was $77.39 \mu \mathrm{mol} / \mathrm{L}$; at $24 \mathrm{~h}, \mathrm{IC} 50$ was $29.65 \mu \mathrm{mol} / \mathrm{L}$; at $36 \mathrm{~h}$, IC50 was $10.56 \mu \mathrm{mol} / \mathrm{L}$; at $48 \mathrm{~h}$, IC50 was $3.79 \mu \mathrm{mol} / \mathrm{L}$ (Fig. 1). In previous study, we found that at $36 \mathrm{~h}, 80 \mu \mathrm{mol} / \mathrm{L}$ PAB induced strongest autophagy than other concentration [7], therefore to detect the relationship of autophagy, cell cycle arrest and senescence, we chose $80 \mu \mathrm{mol} / \mathrm{L}$ PAB in the following experiments.

\section{PAB induced $G 2 / M$ cell cycle arrest at early stage, then autophagy, lastly senescence.}

We could observe that from $12 \mathrm{~h}, \mathrm{PAB}$ begun to induce obvious G2/M cell cycle arrest, but there was no subdiploid peak of apoptosis marker. In control group, the G2/M cell cycle arrest ratio was $12.5 \%$, at $12 \mathrm{~h}$ after PAB treatment it was $52.79 \%$, at $24 \mathrm{~h}$ it was $86.88 \%$, at $36 \mathrm{~h}$ it was $76.83 \%$, at $48 \mathrm{~h}$ it was $65.86 \%$ (Fig. 2A). $80 \mu \mathrm{mol} / \mathrm{L}$ PAB time-dependently increased the positive ratio of MDC staining which marked autophagy, in control group, the ratio was $4.32 \%$, at $12 \mathrm{~h}$ after $\mathrm{PAB}$ treatment it was $4.92 \%$, at $24 \mathrm{~h}$ it was $30.25 \%$, at $36 \mathrm{~h}$ it was $68.23 \%$, at $48 \mathrm{~h}$ it was $72.98 \%$ (Fig. 2B), and our previous study had found that from 24 LC3 II expression was increased which was the maker of autophagy[7], therefore combining the results of the MDC staining and LC3 II expression, it was confirmed that PAB from $24 \mathrm{~h}$ induced autophagy. Senescent cells acquire characteristic morphological changes, such as flatten out and enlargement. At the same time senescent cells can be identified via a biochemical assay that senescence-associated$\beta$-galactosidase at an acidic $\mathrm{pH} 6.0$ was visualized as a blue perinuclear staining [28, 29]. After $80 \mu \mathrm{mol} / \mathrm{L}$ $\mathrm{PAB}$ for $3 \mathrm{~d}$, senescence was detected by SA- $\beta$-galactosidase staining under phase contrast microscopy. It was found that PAB-treated cells were positive after SA- $\beta$-galactosidase staining. Meanwhile the senescent cells acquired characteristic morpho- 
logical changes, such as flatten out and enlargement (Fig. 2C).

\section{The characters of senescent cells}

The characters of senescence-induced by 80 $\mu \mathrm{mol} / \mathrm{L}$ PAB treatment for $3 \mathrm{~d}$ were detected. Senescent cells were multinuclear (Fig. 3A). In senescent cells, the level of autophagy was high, namely flowcytometric analysis detected increasing positive ratio of MDC staining, fluorescence microscopy observed increasing green dots of MDC staining after PAB treatment, and western result showed that the expression of LC3II was increased by PAB treatment (Fig. 3B). In senescent cells, the mitochondrial membrane potential was not decreased in rodanmine 123 staining which was examined by flowcytometry and fluorescence microscopy, respectively (Fig. 3C). In control cells most of them were diploid, but in senescent cells most of them was polyploid (Fig. 3D). Meanwhile DNA fragmentation of senescent cells was not observed, but when 3-MA, an inhibitor of autophagy, together with PAB was used, most of cells died through apoptosis, lastly no senescence (Fig. 3E).

\section{PAB increased PKC activity}

From $12 \mathrm{~h}, \mathrm{PAB}$ obviously increased PKC activity compared to medium group, and which decreased by $8 \mathrm{nmol} / \mathrm{L}$ staurosporine at different time point (Fig. 4).

\section{PKC inhibitor staurosporine or Ro-3 I-8220 inhibited the effect of PAB}

When L929 cells were treated with $80 \mu \mathrm{mol} / \mathrm{L}$ $\mathrm{PAB}$ for $36 \mathrm{~h}$, the cell became larger and rounder than control group, but there was no apoptotic bodies, and debris of dead cell. Together with PKC inhibitor staurosporine or Ro-31-8220, debris of dead cells appeared, and the number of larger and round cells decreased after PAB treatment (Fig. 5A). At $36 \mathrm{~h}$ the

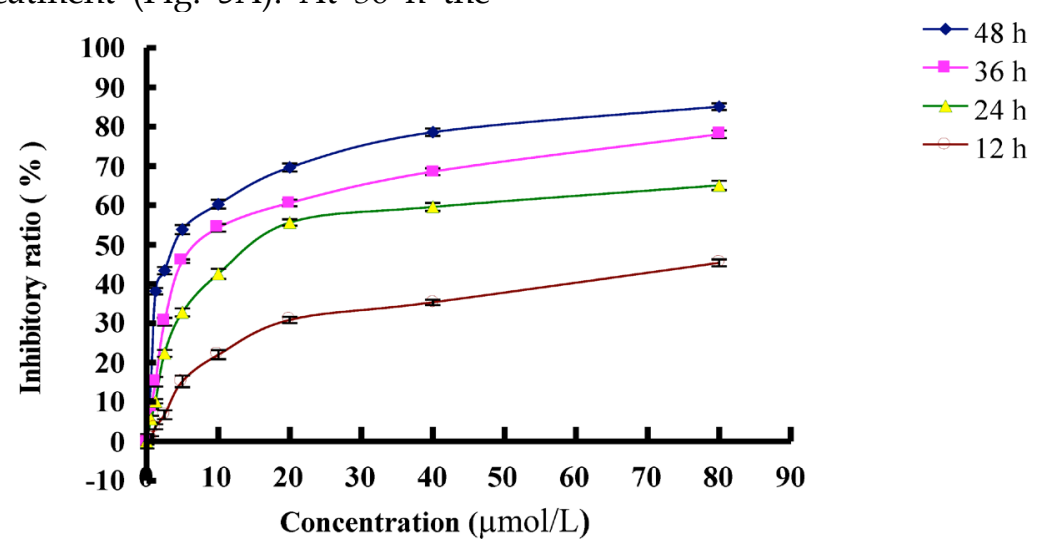

multiple nuclear L929 cells appeared after PAB treatment, and there was no condensed nuclear in cell nuclear fluorescence analysis. But together with PKC inhibitor staurosporine or Ro-31-8220, the number of multiple nuclear L929 cells was decreased after PAB treatment, importantly DNA fragmentations appeared (Fig. 5B). And at $36 \mathrm{~h} \mathrm{G} 2 / \mathrm{M}$ cell cycle arrest appeared after PAB treatment. But together with PKC inhibitor staurosporine or Ro-31-8220, cell cycle arrest was inhibited after PAB treatment, and the apoptotic subdiploid peak appeared (Fig. 5C).

\section{Staurosporine changed cyclinB I expression induced by PAB}

From $12 \mathrm{~h}$, the expression of cyclinB1 was up-regulated, and from $36 \mathrm{~h}$, the expression of cylinB1 was down-regulated after PAB treatment. And the expression of cdc2 was not regulated by PAB (Fig. 6A). Together with staurosporine, at $12 \mathrm{~h}$ PAB could not increase the expression of cyclinB1, but no effect on cdc2 (Fig. 6B).

\section{Staurosporine inhibited autophagy-induced by PAB}

$\mathrm{PAB}$ increased the ratio of MDC positive staining (Fig. 7A), promoted the conversion of LC3 I to LC3II and up-regulated Beclin 1 expression (Fig. 7B), but together with staurosporine, the ratio of MDC positive staining-induced by PAB was decreased. And conversion of LC3 I to LC3II and the up-regulation of Beclin 1 were also inhibited by staurosporine. Caspase 3 was not activated by PAB treatment, but together with staurosporine caspase 3 was activated (Fig. 7C). Meanwhile staurosporine promoted the appearance of DNA fragmentation of PAB-treated cells, which was the marker of apoptosis, but in PAB-treated cells there was no DNA fragmentation (Fig. 7D).

Fig I. The inhibitory effect of different dose of PAB on $\mathrm{L} 929$ cell growth at different time. The cells $\left(I \times I 0^{4}\right.$ cells/well) were incubated with DMEM medium for $24 \mathrm{~h}$, then replaced DMEM medium with different dose of PAB for I2, 24, 36, $48 \mathrm{~h}$. Growth inhibition was evaluated by MTT method. Mean \pm S.D, $\mathrm{n}=$ 3. 

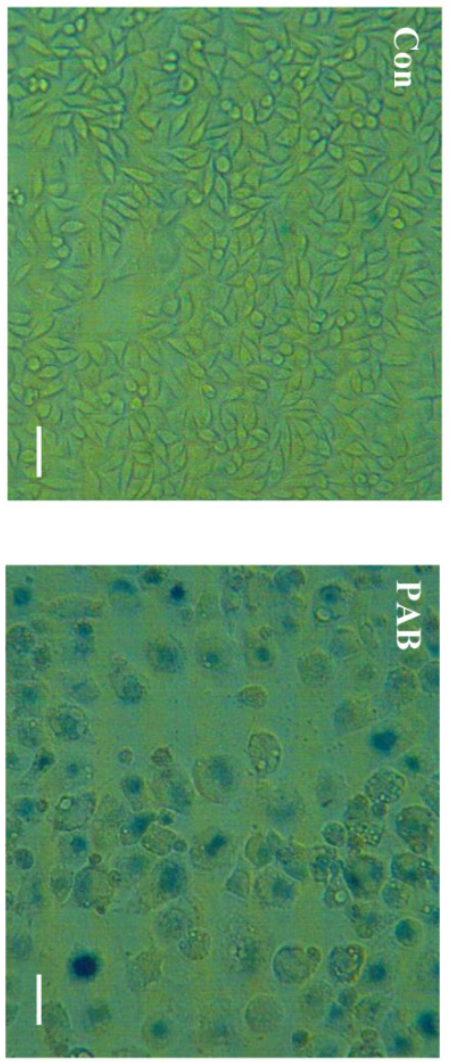
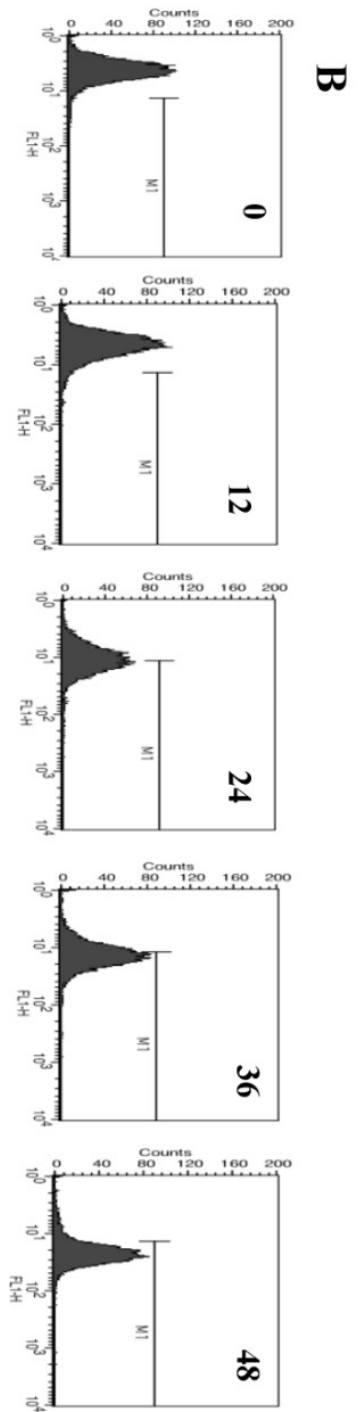

Positive ratio of MDC staining (\%)

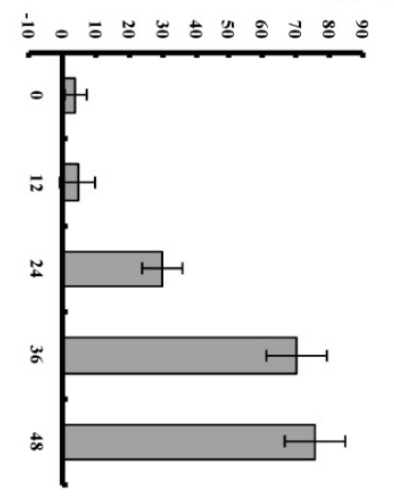

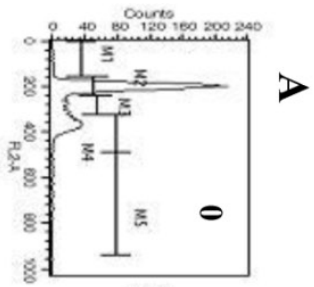
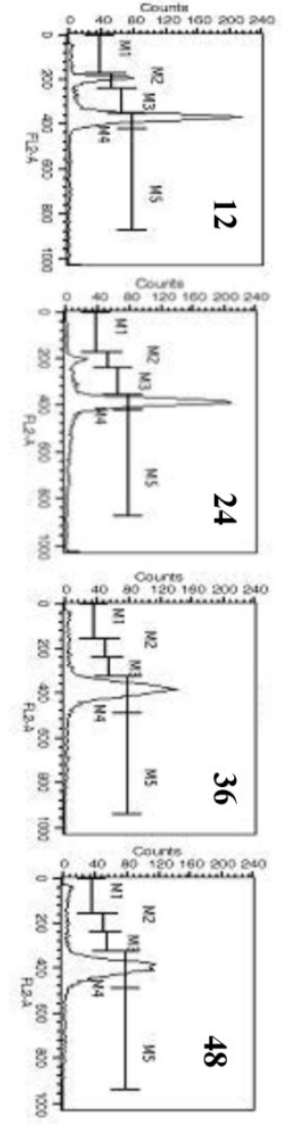

Percentage of G2/M cycle arrest (\%)

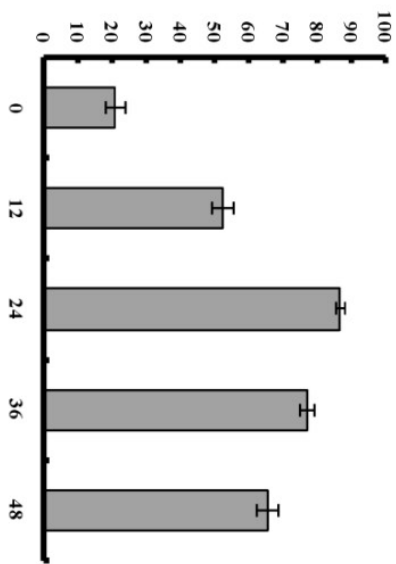

Fig 2. $P A B$ induced cell cycle arrest, autophagy and senescence. A: PAB induced cell cycle arrest. Flowcytometric analysis showed that from $I 2 \mathrm{~h} 80 \mathrm{\mu mol} / \mathrm{L}$ $P A B$ induced obvious cell cycle arrest. $M 2=G 1$ phase, $M 4=G 2$ phase. The right histogram, which showed that at $12 \mathrm{~h}$ after $P A B$ treatment the $G 2 / M$ percentage was $52.79 \%$, but control group was $12.5 \%$, was the numerical analysis of left flowcytometry. Mean \pm S.D, $n=3$. B: PAB increased autophagic ratio. From $24 \mathrm{~h}, 80 \mu \mathrm{mol} / \mathrm{L}$ PAB increased the positive ratio of MDC staining in flowcytometric analysis. The right histogram, which showed that at $24 \mathrm{~h}$ the positive ratio of MDC staining was $30.25 \%$, at $12 \mathrm{~h}$ it was $4.92 \%$ and control group was $4.32 \%$, was the numerical analysis of left flowcytometry. Mean \pm S.D, $n=3$. C: Senescence was observed. After cells were treated with $80 \mu \mathrm{mol} / \mathrm{L}$ PAB for $3 \mathrm{~d}$, the cells became blue in $S A$ - $\beta$-galactosidase staining under phase contrast microscopy. Arrows indicated blue staining. Bar $=45 \mu \mathrm{m}$. 
A
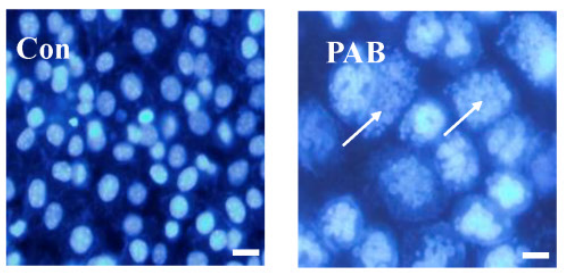

B


Con

PAB

LC3 I

LC3 II

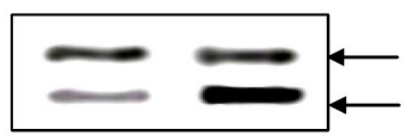

$18 \mathrm{kDa}$

$16 \mathrm{kDa}$


C
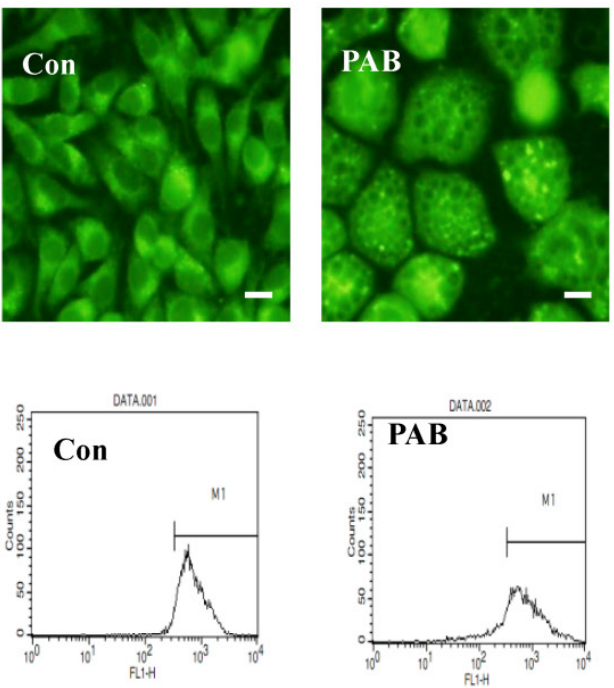

D
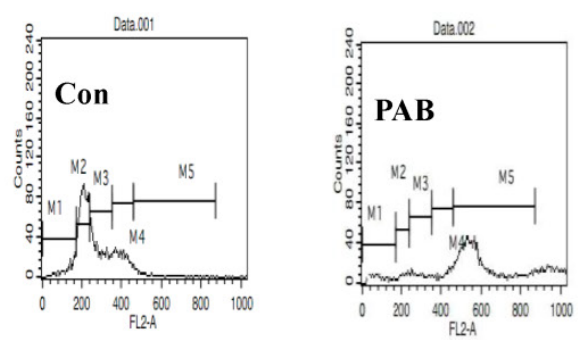

E

S/C LC3 I

S/C LC3 II



Fig 3. The characters of senescence induced by $80 \mu \mathrm{mol} / \mathrm{L} P$ PAB treatment for $3 \mathrm{~d}$. A: Senescent cells were multinuclear. Arrows indicated multinuclear cells. B: In senescent cells, the bright green dots of MDC staining were increased in the morphologic picture, which marked autophagy. And flowcytometric analysis further showed that PAB increased MDC positive ratio. Western result indicted LC3II was formed after PAB treatment. The densitometry was applied to quality the protein density of the Western blot, S C: (band density of the sample after PAB treatment for different time) (band density of control). Triplicate experiments were done. C: In senescent cells, the mitochondrial membrane potential was not decreased. Morphologic analysis showed that senescent cells and control cells had the same density of rodamine 123 staining, and flowcytometric results further showed that mitochondrial membrane potential was same between two groups. D: Most of senescent cells were $4 \mathrm{~N}$ cells, control group were $2 \mathrm{~N}$ cells, but in senescent cells, the number of polyploid was increased. E: In PAB-treated L929 cells, there was no DNA ladder, but combined with 3-MA (autophagy inhibitor), DNA ladder appeared. Bar= $15 \mu \mathrm{m}$. 


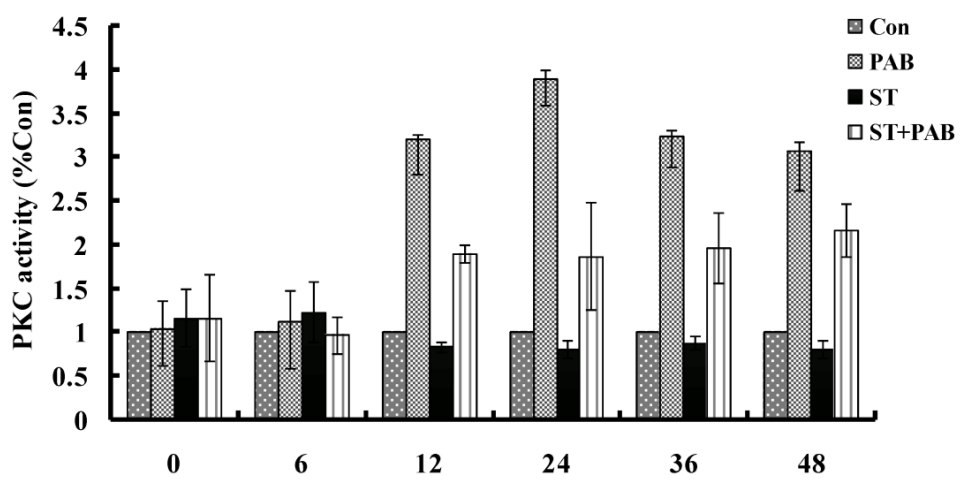

Fig.4. $P A B$ increased PKC activity. From 12 h, PAB increased PKC activity which was decreased by staurosporine, but alone staurosporine did not obviously affect PKC activity.

Fig. 5. Staurosporine restrained the effect of $P A B$. A: At 36 $h, P A B$ did not induce the appearance of apoptotic bodies, and made cells larger that control. But with staurosporine, the apoptotic bodies appeared after PAB treatment, and cell did not become larger, bar $=90 \mu \mathrm{m}$. B: At $36 \mathrm{~h}$, PAB promoted the appearance of multiple nuclei of L929 cells, but together with staurosporine, nuclei were fragmented and condensed, the cell number of multiple nuclei was decreased, bar $=45 \mu \mathrm{m}$. C: PAB promoted cell cycle arrest, but staurosporine inhibited the role of $\mathrm{PAB}$, and promoted the appearance of subdiploid peak which marked apoptosis.
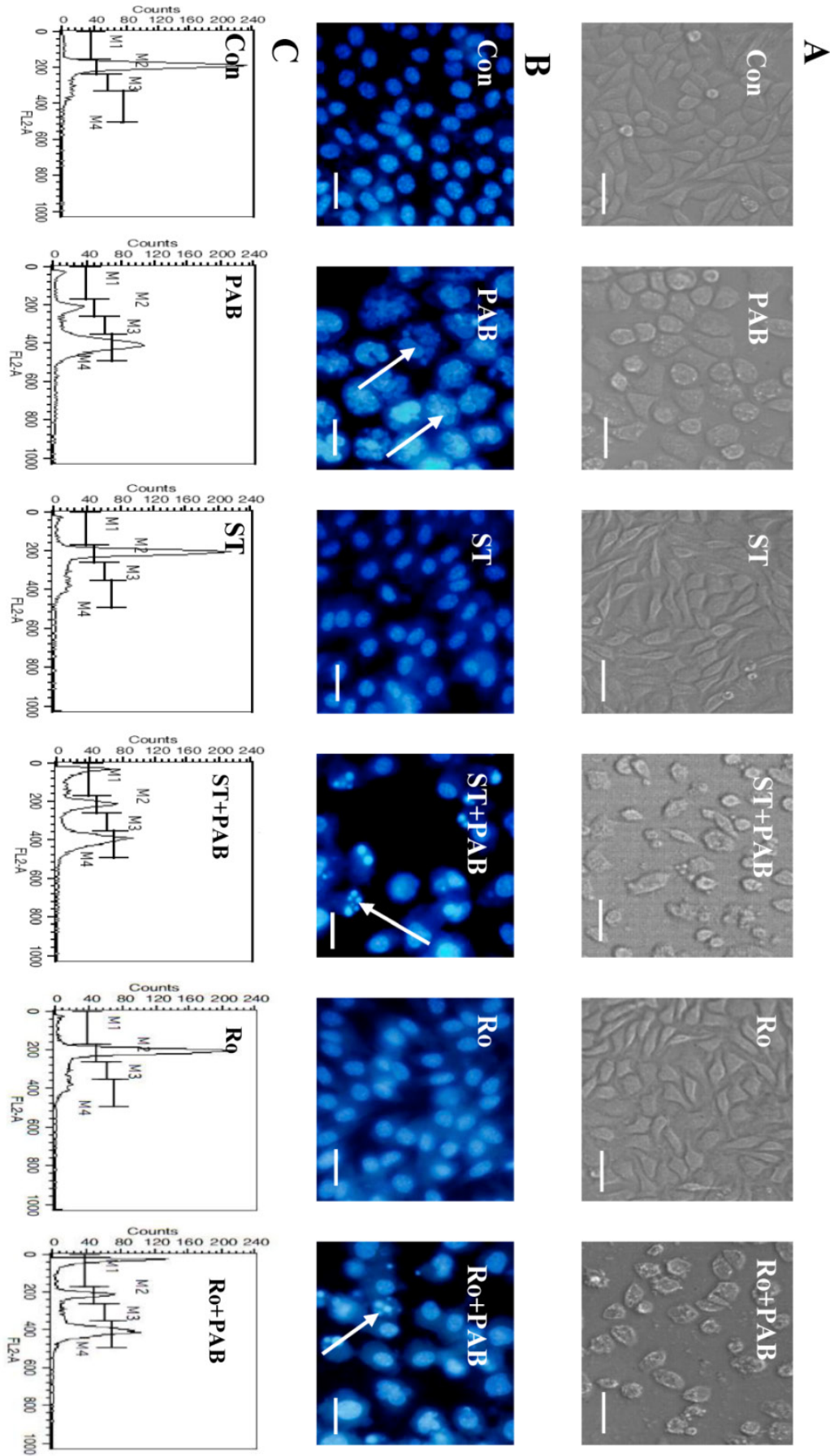


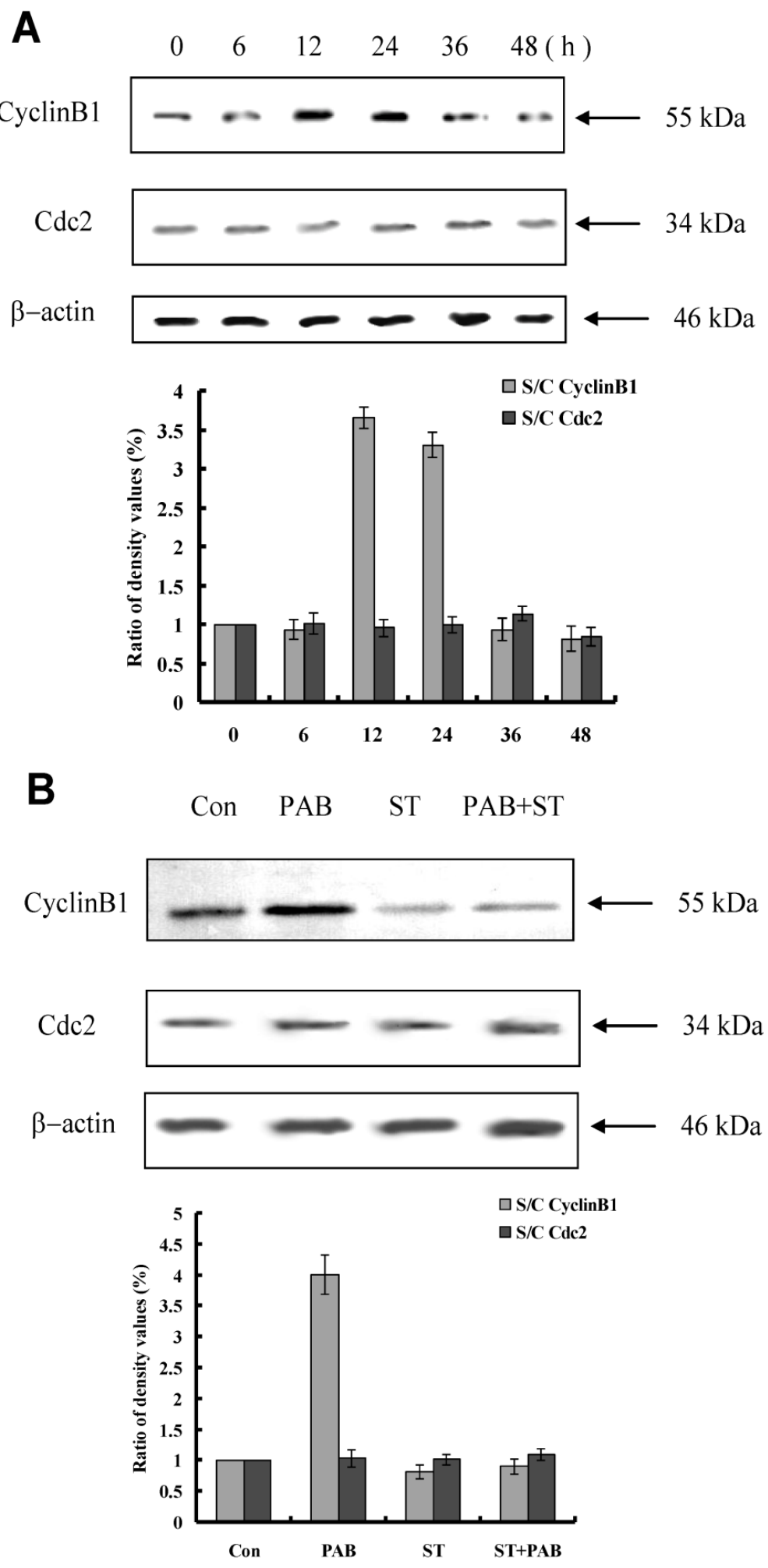

Fig 6. Staurosporine altered the expression of mitotic arrest-related protein in PAB-treated $L 929$ cells. A: PAB up-regulated the expression of cyclinBI at 12 and $24 \mathrm{~h}$, and decreased the expression of cyclin BI from $36 \mathrm{~h}$, and had no effect on cdc2 expression. B: At I2 h, PAB up-regulated cyclin BI expression, together with staurosporine, PAB did not increase cyclinBI expression. 
A

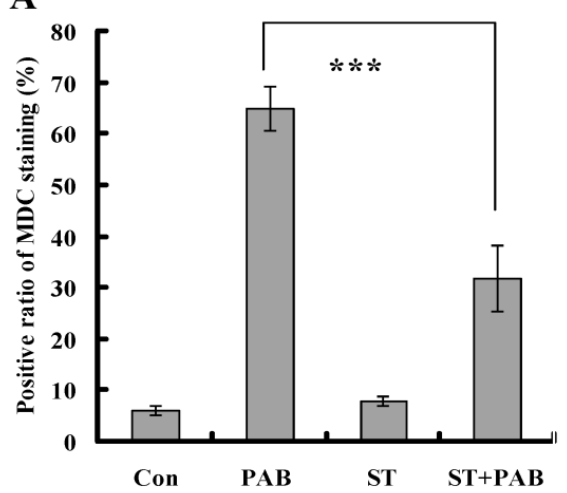

B
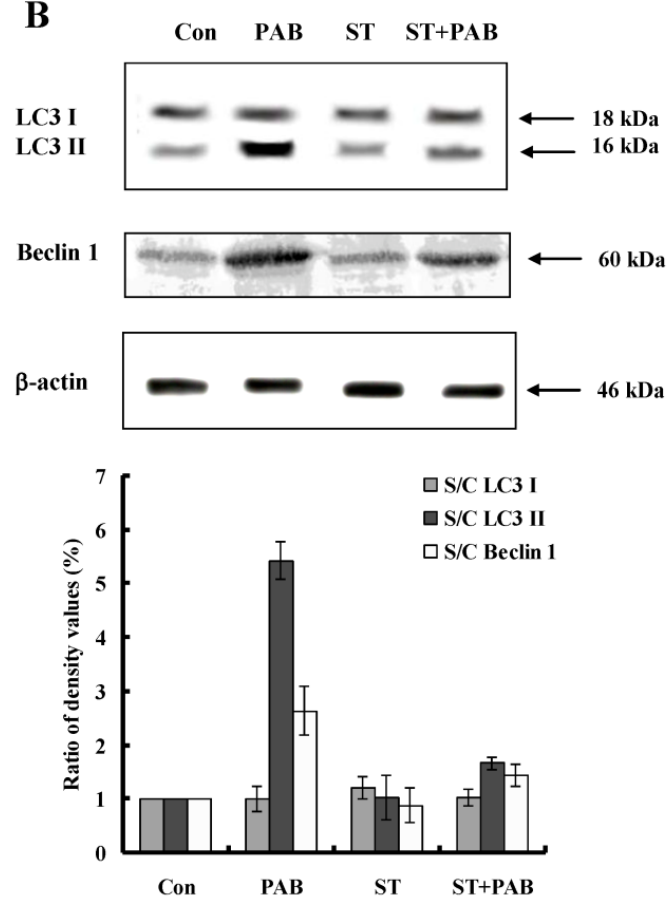

C


D

Fig 7. Staurosporine inhibited autophagy and promoted apoptosis in PAB-treated L929 cells. A: PAB increased MDC positive staining, but was blocked by staurosporine. B: PAB increased the expression of Beclin I and LC3 II expression which marked autophagy, but was inhibited by staurosporine. C: PAB alone could not activate caspase 3, but combined with staurosporine caspase 3 was activated. D: In PAB-treated L929 cells, there was no DNA ladder, but combined with staurosporine DNA ladder appeared.

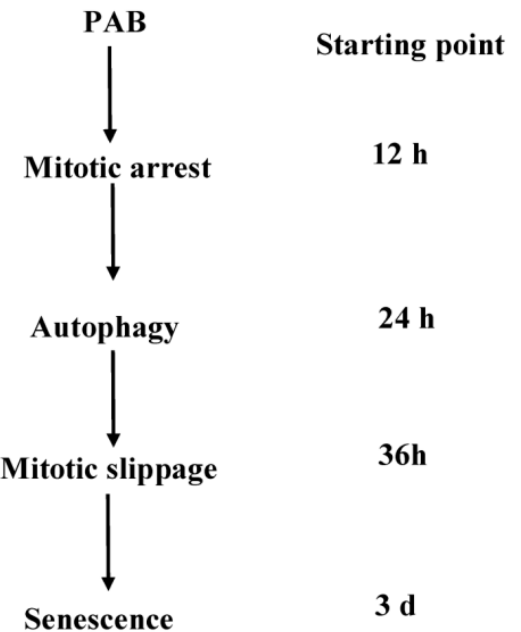

Fig 8. A schematic diagram of the events that occurred during PAB-induced cell death in L929 cells was depicted. PAB induced mitotic arrest then. High dose of $P A B$ induced high level of autophagy which could inhibit apoptosis and then escaped into GI cell cycle, lastly became senescence.

\section{Discussion}

$\mathrm{PAB}$ had potent anti-tumor effect on human breast cancer MCF-7, human cervical cancer HeLa, human melanoma A375 and so on, and most of inhibitory effect on tumor cell was through apoptosis or necrosis [1-6]. But in murine fibrosarcoma L929 cells after PAB treatment we did not observe apoptotic bodies, debris of dead cell under microscope, condensed nuclear in cell nuclear fluorescence analysis, 
and subdiploid peak of apoptosis marker. Taken them together, the inhibitory mechanism of PAB in L929 cell was not through apoptosis. We did not know the detail reasons why in L929 cells there was no apoptosis, but Qi Min [12] reported that caspase 3 was not activated by PAB in L929 cell in $72 \mathrm{~h}$, therefore it was suggested that no caspase 3 activation might be one reason that PAB did not induce apoptosis. Meanwhile our previous study showed that PAB did not decrease mitochondrial membrane potential through up-regulating Bcl-2 expression [7], which might be another reason that $\mathrm{PAB}$ did not induce apoptosis in L929 cells. In this study, we further investigated that in L929 cells after PAB treatment what happened bypass apoptosis.

In our previous study, it was found that $\mathrm{PAB}$ induced L929 cells autophagy [7] and mitotic arrest [12] to inhibit L929 cell growth. But the time sequence of cell cycle arrest and autophagy was not focused. In this study, we found that PAB at $12 \mathrm{~h}$ induced obvious cell cycle arrest, and at $24 \mathrm{~h}$ PAB induced obvious autophagy. Therefore it was confirmed by us that cell cycle arrest was anterior to autophagy in the time sequence. It was reported that G2/M [30] or G1 [31] cell cycle arrest were related to autophagy, but our study confirmed that mitotic arrest was very important to autophagy. Meanwhile it was found that after $80 \mu \mathrm{mol} / \mathrm{L}$ PAB treated for $3 \mathrm{~d}$, L929 cells became senescence, therefore in time sequence cell cycle arrest and autophagy were anterior to senescence.

It was reported that in cell cycle progression cyclinB1/cdc2 complex activity was increased by up-regulating cyclin B1 expression, cyclin B1 levels rised during the $S$ and $G_{2}$ phases for entering $M$ phase, then cyclin B1 should be destroyed before the cells escaped from mitosis [13-17]. It was found that at 12 and $24 \mathrm{~h}$ the expression of cyclin B1 was increased by $\mathrm{PAB}$, indicating that cells had entered mitotic phase. And at $36 \mathrm{~h}$ after PAB treatment, the expression of cyclin B1 was decreased, indicating that cells exited from mitotic phase and entered G1 phase although cells could not divide because of inhibited-tubulin, namely mitotic slippage into G1 cell cycle. And at $24 \mathrm{~h}$ PAB induced high level of autophagy, therefore autophagy happened before mitotic slippage into G1 phase of cell cycle. After mitotic slippage into G1 phase of cell cycle, sencondary apoptosis or permanent G1 cell cycle arrest might occur [16]. In our study, we found that the mitosis-arrested cells induced by $80 \mu \mathrm{mol} / \mathrm{L}$ PAB were survival after $72 \mathrm{~h}$. However Qi Min study showed that $20 \mu \mathrm{mol} / \mathrm{L}$ PAB induced secondary apoptosis after mitotic slippage [12]. Therefore it was supposed that high dose of PAB induced high level of autophagy, which could inhibit apoptosis after mitotic arrest, but low level of autophagy-induced by low dose of PAB could not antagonize apoptosis after mitotic arrest. Therefore it was concluded that the level of autophagy might determine the destination of cells after mitotic arrest.

Some a study proved that autophagy impairment induced premature senescence [23], but we found that senescent cells were accompanied with high level of autophagy, which was consistent with Capparelli C's study [22]. Meanwhile L929 cells-treated with PAB after mitotic slippage cells entered G1 cell cycle and formed multinucleated cells, these multinucleated cells could survive and became senescent which was consistent with Klein LE's study [17]. Meanwhile senescent cells had normal mitochondrial membrane potential, and it was reported that decreased mitochondrial membrance led to apoptosis, indicating that normal mitochondrial memebrane potential were important to senescent cell survival bypass apoptosis.

PKC had important role in cell biological function. PKC enzymes were also shown to play a role in G2/M transition. The suggested mechanism of PKC was suppression of cdc2 activity. But most of the published data strongly implicated PKC in lamin B phosphorylation and nuclear envelope disassembly [32]. In this study we found that at $12 \mathrm{~h}$ after PAB treatment cyclin B1 expression was up-regulated, but together with PKC inhibitor staurosporine the up-regulation of cyclin B1 by PAB was blocked. Therefore we confirmed that PKC promoted mitosis entry, and inhibiting PKC activity blocked mitotic cell cycle arrest-induced by PAB. Meanwhile we found that staurosporine at $36 \mathrm{~h}$ inhibited the occurrence of autophagy-induced by PAB. Therefore it was confirmed that PKC inhibitor staurosporine inhibited mitotic arrest and led to decreased autophagy-induced by PAB. And because staurosporine together with $\mathrm{PAB}$ induced cell death, we could not observe the senescence after PAB treatment. In Gong Xianfeng study [4], PAB induced apoptosis through activating PKC in HeLa cells, and PKC inhibitor staurosporine partly blocks this effect, we inferred that in HeLa and L929 cells, PAB activated the same PKC isoforms, but because of different down stream proteins in HeLa and L929 cells, PAB induced apoptosis and autophagy in HeLa and L929 cells, respectively. And about what PKC isoforms was activated would be done in the future study. Meanwhile staurosporine was known to induce apoptosis directly [33], but in this study, low dose of staurosporine was used and staurosporine alone did not induce apoptosis, therefore it was speculated that staurosporine promoted PAB-treated cell death was not related to 
the apoptotic effect of staurosporine.

Therefore in L929 cells, PAB induced mitotic arrest, autophagy and senescence in the time sequence through activating PKC.

\section{Acknowledgements}

This work was supported by Adiministration of Traditional Chinese Medicine of Jilin Province (2010-pt064 and 2012-030).

\section{Competing Interests}

The authors have declared that no competing interest exists.

\section{References}

1. Pan DJ, Li ZL, Hu CQ, et al. The cytotoxic principles of Pseudolarix Kaempferi: Pseudolaric acid-A and B and related derivatives. Planta Med. 1990; 56: 383-5.

2. Gong XF, Wang MW, Tashiro SI, et al. PAB induces apoptosis through P53 and Bax/Bcl-2 pathways in human melanoma A375-S2 cell. Arch Pham Res. 2005; 28: 68-72.

3. Zhang M, Mo X, Chen XY, et al. Studies of apoptosis on K562 cell line induced by pseudolaricd acid B in vitro. Chinese Trad Herb Drugs. 2002; 33: 533-5.

4. Gong XF, Wang MW, Tashiro SI, et al. Involvement of JNK-initiated p53 accumulation and phosphorylation of p53 in pseudolaric acid B induced cell death. Exp Mol Med. 2006; 38: 428-34.

5. Yu JH, Cui Q, Jiang YY, et al. Pseudolaric acid B induced apoptosis, senescence, and mitotic arrest in human breast cancer MCF-7. Acta Pharmacol Sin. 2007; 28(12):1975-83.

6. Yu JH, Wang HJ, Li XR, et al. Protein tyrosine kinase, JNK, and ERK involvement in pseudolaric acid B-induced apoptosis of human breast cancer MCF-7 cells. Acta Pharmacol Sin. 2008; 29(9):1069-76.

7. $\mathrm{Yu} \mathrm{JH}, \mathrm{Li} \mathrm{XR}$, Tashiro SI, et al. Bcl-2 family proteins were involved in Pseudolaric acid B-induced autophagy in murine fibrosarcoma L929 Cells. J Pharmacol Sci. 2008; 107(3): 295-302.

8. 8 Wong VK, Chiu P, Chung SS, et al. Pseudolaric acid B, a novel microtubule-destabilizing agent that circumvents multidrug resistance phenotype and exhibits antitumor activity in vivo. Clin Cancer Res. 2005; 11 : 6002-11.

9. Blagosklonny MV,Fojo T. Molecular effects of paclitaxel: Myths and reality. Int J Cancer. 1999; 83: 151-6.

10. Horitz SB. Mechanism of action of taxol. Trends Pharmacol Sci. 1992;13: $134-6$.

11. Jordan MA, Wilson L. Microtubules as a target for anticancer drugs. Nat Rev Cancer. 2004; 4: 253-6.

12. Qi M, Yao GD, Fan SM, et al. Pseudolaric acid B induces mitotic catastrophe followed by apoptotic cell death in murine fibrosarcoma L929 cells. Eur J Pharmacol. 2012; 683: 16-26.

13. Peter $M$, Nakagawa J, Doree $M$, et al. In vitro disassembly of the nuclear lamina and $\mathrm{M}$ phase-specific phosphorylation of lamins by cdc2 kinase. Cell. 1990; 61:591-602

14. Courvalin JC, Segil N, Blobel G, et al. The lamin B receptor of the inner nuclear membrane undergoes mitosis-specific phosphorylation and is a substrate for p34cdc2-type protein kinase. J Biol Chem. 1992; 267: 19035-8.

15. Rieder CL, Maiato H. Stuck in division or passing through: What happens when cells can-not satisfy the spindle assembly check point. Dev Cell. 2004; 7: 637-51.

16. Mikhail V. Blagosklonny. Mitotic Arrest and Cell Fate. Cell Cycle. 2007; 6: $70-4$.

17. Klein LE, Freeze BS, Smith AB, et al. The microtubule stabilizing agent discoder-molide is a potent inducer of accelerated cell senescence. Cell Cycle. 2005; 4: 501-17.

18. Campisi J, d'Adda di Fagagna F. Cellular senescence: when bad things happen to good cells. Nat Rev Mol Cell Biol. 2007; 8: 729-740.

19. Itahana K, Campisi J, Dimri GP. Methods to detect biomarkers of cellular senescence: the senescence-associated beta-galactosidase assay. Methods Mol Biol. 2007; 371: 21-31
20. Kurz T, Terman A, Brunk UT. Autophagy, ageing and apoptosis: the role of oxidative stress and lysosomal iron. Arch Biochem Biophys. 2007; 462: $220-230$.

21. Gerland LM, Peyrol S, Lallemand C, et al. Association of increased autophagic inclusions labeled for beta-galactosidase with fibroblastic aging. Exp Gerontol. 2003; 38:887-95.

22. Capparelli C, Guido C, Whitaker-Menezes D, et al. Autophagy and senescence in cancer-associated fibroblasts metabolically supports tumor growth and metastasis via glycolysis and ketone production. Cell cycle. 2012; 11(12): 2285-302.

23. Kang HT, Lee KB, Kim SY, et al. Autophagy Impairment Induces Premature Senescence in Primary Human Fibroblasts. Plos one. 2011; 6(8):e23367.

24. Black JD. Protein kinase C-mediated regulation of the cell cycle. Front Biosci. 2000; 5: 406-23.

25. Collas P, Thompson L, Fields AP, et al. Protein kinase C-mediated interphase lamin B phosphorylation and solubilization. J Biol Chem. 1997;272(34): 21274-80.

26. Kadate T, Jeng AY, Blumberg PM. Comparison of protein kinase C functional assays to clarify mechanisms of inhibitor action. Biochem Pharmacol. 1988;37:1541-1545.

27. Lee YJ, Won AJ, Lee J, et al. Molecular Mechanism of SAHA on Regulation of Au-tophagic Cell Death in Tamoxifen-Resistant MCF-7 Breast Cancer Cells. Int J Med Sci. 2012; 9(10):881-93.

28. Shelton DN, Chang E, Whittier PS, et al. Microarray analysis of replicative senescence. Curr Biol. 1999; 9: 939-45.

29. Dimri GP, Lee X., Basile G, et al. A biomarker that identifies senescent human cells in culture and in aging skin in vivo. Proc Natl Acad Sci U S A. 1995; 92: 9363-7.

30. Zhu JS, Ouyang DY, Shi ZJ, et al. Cucurbitacin B induces cell cycle arrest, apoptosis and autophagy associated with $\mathrm{G}$ actin reduction and persistent activation of cofilin in Jurkat cells. Pharmacology. 2012;89(5-6):348-6.

31. Yu XJ, Han QB, Wen ZS, et al. Gambogenic acid induces G1 arrest via GSK3 $\beta$-dependent cyclin D1 degradation and triggers autophagy in lung cancer cells. Cancer Lett. 2012;322(2):185-94.

32. Chae HJ, Kang JS, Byun JO, et al. Molecular mechanism of staurosporine-induced apoptosis in osteoblasts. Pharmacol Res. 2000; 42 (4): 373-381.

33. Zhang XD, Gillespie SK, Hersey P. Staurosporine induces apoptosis of melanoma by both caspase-dependent and -independent apoptotic pathways. Mol Cancer Ther. 2004;3(2):187-97.

\section{Author biography}

Dr Xiao fang Yu was called back as experts of "Thousand Talents Program" by Organization Department of the CPC Central Committee in 2010, now is working as the director of the Institute of Virology and AIDS Research of Jilin University, who majors in the relationship between virus and host cell, and cancer research, he had published high level of paper in Nature, Science, and so on.

Dr Xian ying Meng majors in cancer research and clinical therapy of cancer, especially the clinical operation of Thyroid cancer.

Dr Jing hua Yu majors in the relationship of autophagy, apoptosis and cell cycle arrest of cancer cells after drug treatment, and do relative research for 10 years. Currently she focuses on the effect of virus on autophagy, apoptosis and cell cycle arrest of host cells. 